Zagazig J. Agric. Res., Vol. 43 No. (2) 2016

http:/www.journals.zu.edu.eg/journalDisplay.aspx?Journalld=1\&queryType=Master

\title{
IN VITRO MICROPROPAGATION OF Aglaonema commutatum SCHOTT
}

\author{
Mohamed M. Abass $^{1 *}$, H. A. El-Shamy ${ }^{2}$, A. Kamel Dawh ${ }^{2}$ and Sawsan S. Sayed ${ }^{1}$ \\ 1. Ornamental Plants Dept., Hort. Res. Inst., Agric. Res. Cent., Giza, Egypt \\ 2. Hort. Dept., Fac. Agric., Zagazig Univ., Egypt
}

\begin{abstract}
Different concentrations $(0.0,1.0,2.0,4.0,8.0$ or $16.0 \mathrm{mg} / \mathrm{l})$ of cytokinins (benzyladenine, kinetin or isopentenyladenine) were investigated in order to enhance shoot multiplication of Aglaonema commutatum. Results indicated that benzyladenine (BA) at $8.0 \mathrm{mg} / \mathrm{l}$ gave the highest number of shoots/ explant (4.08). Different concentrations (0.0, 0.5, 1.0 or $2.0 \mathrm{mg} / \mathrm{l})$ of auxins (indoleacetic acid or naphthaleneacetic acid) combined with $8.0 \mathrm{mg} / \mathrm{l} \mathrm{BA}$ were tested to improve shoot multiplication. $\mathrm{NAA}$ at $0.5 \mathrm{mg} / \mathrm{l}$ combined with $8.0 \mathrm{mg} / \mathrm{l} \mathrm{BA}$ proved to be the best treatment for obtaining the maximum number of shoots/explant (6.70). For root formation induction, shoots obtained from multiplication stage were transferred to MS medium contained different concentrations $(0.00,0.25$, $0.50,1.00$ or $2.00 \mathrm{mg} / \mathrm{l}$ ) of auxins (indoleacetic acid, naphthaleneacetic acid or indole-3-butyricacid). Results showed that $1.0 \mathrm{mg} / \mathrm{l}$ of IAA or NAA were the best treatments for root induction and quality during rooting stage. Rooted shoots were acclimatized by transferring them to plastic pots containing peat moss, vermiculite, perlite or sand each alone or in different combinations among them at equal volume proportions. Perlite and peat moss at equal volume proportions seemed to be the best medium for plantlets acclimatization.
\end{abstract}

Key words: Aglaonema commutatum Schott, 2iP, BA, Kin, NAA, IAA, IBA, micropropagation.

\section{INTRODUCTION}

Aglaonema, commonly referred to as Chinese Evergreens, is a monocotyledonous genus belonging to the family Araceae. Aglaonema has been produced as an ornamental foliage plant for interiorscaping due to its attractive foliage, easiness to grow and tolerance to low relative humidity and low light conditions (Henny, 2000 ; Chen et al., 2005).

Commercial Aglaonema production almost exclusively starts from cuttings. Cutting propagation, however, may transmit pathogens from stock plants to cuttings. Additionally, some Aglaonema cultivars may host endogenous pathogens in their vascular tissue (Chase, 1997), which could make cuttings a source for carrying and spreading disease.

*Corresponding author: Tel. : +201002388713

E-mail address: mmm_abass1984ag@yahoo.com
The rooting of cuttings and division of basal shoots or suckers are the main methods of Aglaonema propagation since micropropagation (tissue culture) has not been successful with this genus mainly due to the difficulty of establishing/maintaining aseptic culture (Chen and Yeh, 2007), low rate of shoot multiplication (Zhang et al., 2004; Chen and Yeh, 2007) and lack of detailed technical information on the micropropagation procedure (Mariani et al., 2011). Little research has been done on micropropagation of Aglaonema using apical or axillary shoot explants (Fang et al., 2013). Only one attempt has been done to micropropagate Aglaonema commutatum (Zhang et al., 2004).

The effect of cytokinins is most noticeable in tissue cultures where they are used, often together with auxins, to stimulate cell division and control morphogenesis. Added to shoot 
culture media, these compounds overcome apical dominance and release lateral buds from dormancy. Cytokinins are very effective in promoting direct or indirect shoot initiation. They are used for this purpose in combination with auxins. A balance between auxin and cytokinin normally gives the most effective organogenesis. The effect of cytokinins on tissue or organ cultures can vary according to the particular compound used. A requirement for a particular cytokinin is sometimes noted for the promotion of direct or indirect adventitious shoot formation (George et al., 2008).

The auxin: cytokinin ratio represents an important signal in the formation of cell phenotype and also in the onset and maintenance of the process of cell division (Stickens et al., 1996). The ability of auxins (together with cytokinins) to manage key events in plant morphogenesis was documented. An auxin is almost invariably required to promote the initial growth of meristem and shoot tip explants.

A low concentration of auxin is often beneficial in conjunction with high levels of cytokinin at stage II when shoot multiplication is required, although in some cases cytokinin alone is sufficient. It is important to choose an auxin at a concentration that will promote growth without inducing callus formation. On the other side, rhizogenesis is usually achieved by treatment with auxin alone (George et al., 2008). So that different concentrations of cytokinins (i.e., Kinetin, isopentenyladenine or benzyladenine) alone or combined with different concentrations of auxins (viz; indoleacetic acid or naphthaleneacetic acid) were tested in order to induction of shoot initiation in this study. Also, the effect of auxin type and concentration on root formation during rooting stage was investigated.

The objective of present study was to establish a preliminary protocol for micropropagation of Aglaonema commutatum by investigating some factors affecting the in vitro propagation such as: cytokinin type and concentration, auxin type and concentration during multiplication and rooting stages as well as planting medium type during acclimatization stage.

\section{MATERIALS AND METHODS}

This study was carried out in Plant Tissue Culture Laboratory of Horticulture Department, Faculty of Agriculture, Zagazig University, throughout the period of 2012- 2015.

Shoot tips (1.5 cm long) were excised from Aglaonema commutatum Schott plants grown in greenhouse and used in this study as explants. Explants were rinsed under running water for one hour with few drops of tween twenty, and then soaked for $30 \mathrm{~min}$. in antifungal solution (Moncut) at a concentration of $3 \mathrm{~g} / \mathrm{l}$. The explants have been immersed in Savlon at 15\% for $10 \mathrm{~min}$. before immersing them in alcohol (70\%) for two min. The explants were then immersed in mercuric chloride solution (MC) at a concentration of $0.3 \%$ for $15 \mathrm{~min}$. under aseptic conditions in a laminar air-flow cabinet. The explants were then immersed in commercial Clorox solution ( $\mathrm{NaOCl}, 5.25 \%$ free chlorine) at $30 \%$ for 15 min. Explants were thoroughly rinsed three times with sterile distilled water after each previous step. Explants were inoculated in glass jars $(60 \times 120 \mathrm{~mm})$ containing Murashige and Skoog (1962) basal medium with $30 \mathrm{~g} / \mathrm{l}$ sucrose, free from growth regulators. After six weeks uncontaminated shoots (about $2.0 \mathrm{~cm}$ length) were transferred to the following experiments.

Shoots (about $2.0 \mathrm{~cm}$ length) obtained from establishment stage were separated and transferred to MS medium supplemented with different concentrations $(0.0,1.0,2.0,4.0,8.0$ or $16.0 \mathrm{mg} / \mathrm{l}$ ) of kinetin (Kin), isopentenyladenine (2iP) or benzyladenine (BA).

Since BA at $8 \mathrm{mg} / \mathrm{l}$ proved to be the best cytokinin treatment, this treatment was tested in combinations with different concentrations ( 0.0 , $0.5,1.0$ or $2.0 \mathrm{mg} / \mathrm{l}$ ) of indoleacetic acid (IAA) or naphthaleneacetic acid (NAA). Shoot proliferation (\%), number of shoots/ explant, number of leaves/ shoot and shoot length $(\mathrm{cm})$ data were recorded after twelve weeks from inoculation date.

The best multiplication treatment $(8.0 \mathrm{mg} / \mathrm{l}$ $\mathrm{BA}+0.5 \mathrm{mg} / \mathrm{l} \mathrm{NAA}$ ) was repeated in order to obtain enough shoots for later rooting experiments. These shoots were transferred to 
MS medium contained different concentrations $(0.0,0.25,0.5,1.0$ or $2.0 \mathrm{mg} / \mathrm{l})$ of NAA, IAA or indole-3-butyric acid (IBA). Data (i.e., root formation (\%), number of roots/shoot, root length $(\mathrm{cm})$, number of leaves/shoot and shoot length, $\mathrm{cm}$ ) were recorded after twelve weeks from inoculation date.

Each treatment of the above mentioned experiments was consisted of 15 jars $(60 \times 120$ $\mathrm{mm}$ ), each one contained about $50 \mathrm{ml}$, and one shoot was inoculated in each jar.

The above mentioned experiment cultures were incubated at $25 \pm 2^{\circ} \mathrm{C}$ under $16 \mathrm{hr}$. photoperiod with 2000 Lux.

Similar shoots (about $2.7 \mathrm{~cm}$ length) were rooted on MS medium fortified with $1.0 \mathrm{mg} / \mathrm{l}$ NAA in order to obtain enough rooted shoots. The plantlets were then transferred to plastic pots $(9 \times 7 \mathrm{~cm})$ containing peat moss, peat moss + perlite $(1: 1, V / V)$, perlite + peat moss + vermiculite $(1: 1: 1 \mathrm{~V} / \mathrm{V} / \mathrm{V})$, perlite + peat moss + vermiculite + sand $(1: 1: 1: 1 \mathrm{~V} / \mathrm{V} / \mathrm{V} / \mathrm{V})$, peat moss + vermiculite $(1: 1 \mathrm{~V} / \mathrm{V})$, peat moss + sand $(1: 1$ $V / V)$ or peat moss + vermiculite + sand $(1: 1: 1$ $V / V / V)$. Each treatment consisted of 20 pots, and each one contained one plantlet. The cultured pots were covered with polyethylene bags for six weeks before removing them. The plantlets were hold in greenhouse at about $25^{\circ} \mathrm{C}$. The survival percentage was recorded after eight weeks.

The statistical layout of all experiments was simple completely randomized design. All collected data were analyzed with analysis of variance (ANOVA) procedure using the MSTAT-C Statistical Software Package (Michigan State University, 1983). Differences between means were compared by using Duncan's multiple range test (Gomez and Gomez, 1984).

\section{RESULTS AND DISCUSSION}

\section{Effect of BA Concentration on Shoot Proliferation and Growth}

Table 1 and Fig. 1 show no effect for supplementation the medium with BA on shoot proliferation since all applied treatments gave $100 \%$ shoot proliferation.
Number of shoots/explant was significantly increased by increasing the concentration of BA. There were no significant differences between 1.0 and $2.0 \mathrm{mg} / \mathrm{l}$ or between 8.0 and $16.0 \mathrm{mg} / \mathrm{l}$. The later concentrations produced the highest number of shoots/explant (4.08 and 4.60 shoots, respectively).

Addition of BA to the medium significantly decreased the number of leaves/shoot. In most cases there were no significant differences among different concentrations of BA in this connection. Shoot length was also followed similar trend of number of leaves / shoot. The highest number of leaves / shoot (4.66) and shoot length $(4.83 \mathrm{~cm})$ were belonged to control treatment (MS medium without growth regulators).

This result indicates the efficiency of higher concentrations ( 8.0 and $16.0 \mathrm{mg} / \mathrm{l}$ ) of $\mathrm{BA}$ in enhancing shoot multiplication compared with lower concentrations and control treatments. Similar findings were recorded by Abdi et al. (2013) on Aloe vera, Hang et al. (2013) on Philodendron xanadu and Fang et al. (2013) on Aglaonema 'Lady Valentine'. It is worth to mention that, from an economic point of view, it is better to use low concentration of BA (8.0 $\mathrm{mg} / \mathrm{l})$ than higher one $(16.0 \mathrm{mg} / \mathrm{l})$ since there was no significant difference between both of them.

\section{Effect of Kin Concentration on Shoot Proliferation and Growth}

As shown in Table 2 and Fig. 2 there was no effect for Kin concentration on shoot proliferation. Number of shoots/explant was slightly enhanced by increasing Kin concentration. The highest significant number of shoots (2.53 and 2.92) were gained with the maximum concentrations $(8.0$ and $16.0 \mathrm{mg} / \mathrm{l}$, respectively) of Kin without significant difference between both of them. On the other hand, number of leaves/ shoot was significantly declined by addition of Kin to the medium. There were no significant differences among all applied concentrations of Kin. Also, shoot length followed similar trend of number of leaves since control treatment attained the maximum shoot length $(4.83 \mathrm{~cm})$. 
Table 1. Effect of benzyladenine (BA) concentration on shoot proliferation and growth of Aglaonema commutatum during multiplication stage after 12 weeks

\begin{tabular}{ccccc}
\hline BA conc. (mg/) & $\begin{array}{c}\text { Shoot } \\
\text { proliferation (\%) }\end{array}$ & $\begin{array}{c}\text { No. of shoots/ } \\
\text { explant }\end{array}$ & $\begin{array}{c}\text { No. of leaves/ } \\
\text { shoot }\end{array}$ & $\begin{array}{c}\text { Shoot } \\
\text { length }(\mathbf{c m})\end{array}$ \\
\hline $\mathbf{0 . 0}$ & 100 & $1.13 \mathrm{~d}$ & $4.66 \mathrm{a}$ & $4.83 \mathrm{a}$ \\
$\mathbf{1 . 0}$ & 100 & $2.33 \mathrm{c}$ & $3.26 \mathrm{~b}$ & $2.89 \mathrm{~b}$ \\
$\mathbf{2 . 0}$ & 100 & $2.33 \mathrm{c}$ & $2.78 \mathrm{bc}$ & $2.08 \mathrm{c}$ \\
$\mathbf{4 . 0}$ & 100 & $3.13 \mathrm{~b}$ & $2.77 \mathrm{bc}$ & $2.45 \mathrm{bc}$ \\
$\mathbf{8 . 0}$ & 100 & $4.08 \mathrm{a}$ & $2.60 \mathrm{c}$ & $2.26 \mathrm{bc}$ \\
$\mathbf{1 6 . 0}$ & 100 & $4.60 \mathrm{a}$ & $2.74 \mathrm{bc}$ & $2.01 \mathrm{c}$
\end{tabular}

* Means having the same letter (s) within the same column are not significantly different according to Duncan's multiple range test at $5 \%$ level of probability.

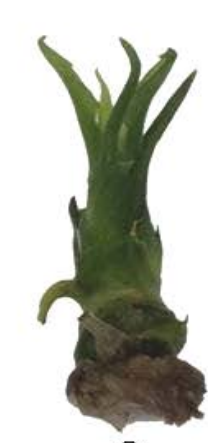

A

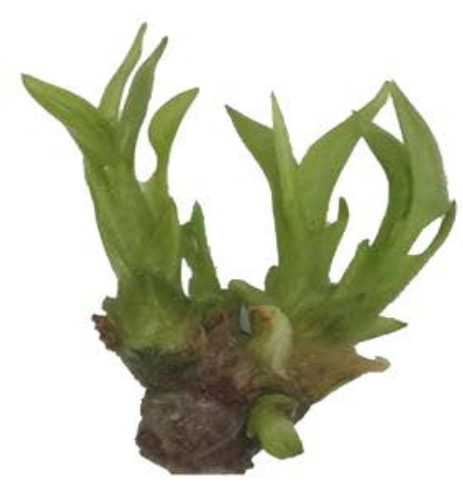

D

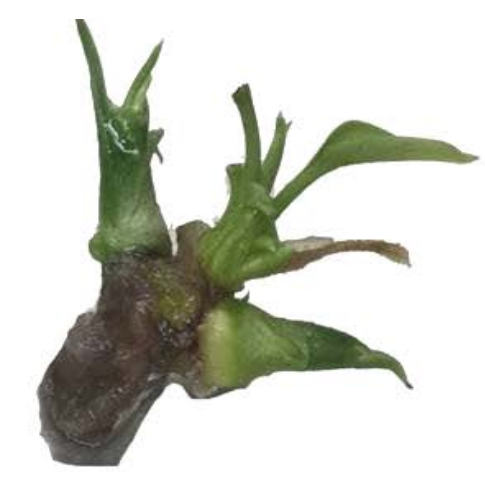

B

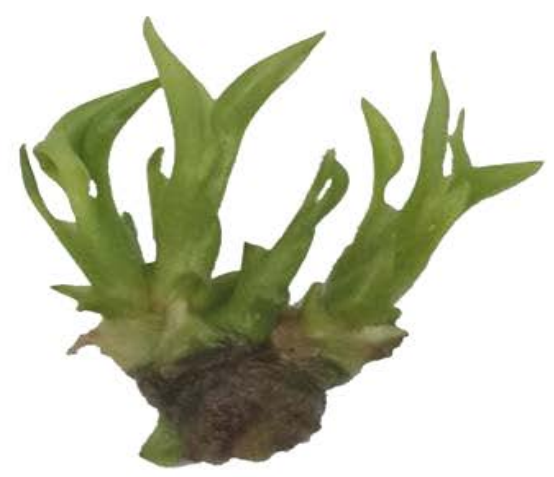

$\mathbf{E}$

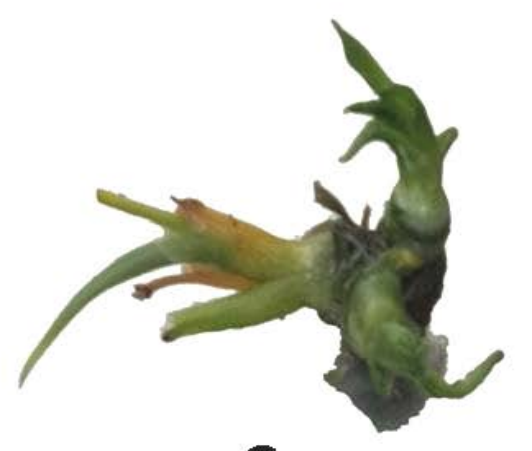

C

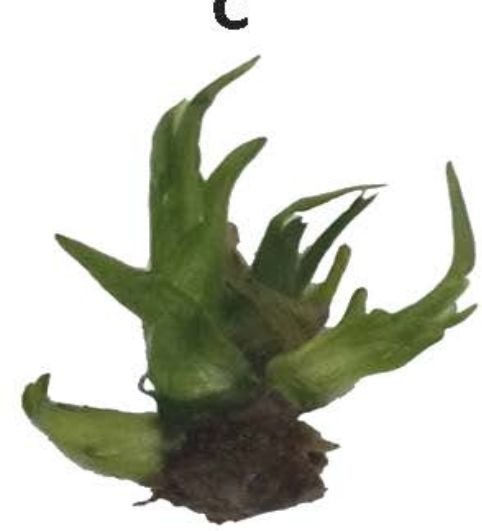

$\mathbf{F}$

Fig. 1. Aglaonema commutatum shoot growth and multiplication as affected by different concentrations of benzyladenine (BA) during multiplication stage after 12 weeks. A (without growth regulators), B (1.0 mg/l), C (2.0 mg/l), D (4.0 mg/l), E (8.0 mg/l) and F (16.0 mg/l) 
Table 2. Effect of kinetin (Kin) concentration on shoot proliferation and growth of Aglaonema commutatum during multiplication stage after 12 weeks

\begin{tabular}{ccccc}
\hline Kin conc. (mg/l) & $\begin{array}{c}\text { Shoot proliferation } \\
\mathbf{( \% )}\end{array}$ & $\begin{array}{c}\text { No. of shoots/ } \\
\text { explant }\end{array}$ & $\begin{array}{c}\text { No. of } \\
\text { leaves/ shoot }\end{array}$ & $\begin{array}{c}\text { Shoot length } \\
(\mathbf{c m})\end{array}$ \\
\hline $\mathbf{0 . 0}$ & 100 & $1.13 \mathrm{c}$ & $4.66 \mathrm{a}$ & $4.83 \mathrm{a}$ \\
$\mathbf{1 . 0}$ & 100 & $1.07 \mathrm{c}$ & $2.76 \mathrm{~b}$ & $3.00 \mathrm{~b}$ \\
$\mathbf{2 . 0}$ & 100 & $1.61 \mathrm{~b}$ & $2.44 \mathrm{~b}$ & $2.61 \mathrm{bc}$ \\
$\mathbf{4 . 0}$ & 100 & $1.76 \mathrm{~b}$ & $2.84 \mathrm{~b}$ & $2.83 \mathrm{bc}$ \\
$\mathbf{8 . 0}$ & 100 & $2.53 \mathrm{a}$ & $2.46 \mathrm{~b}$ & $2.31 \mathrm{bc}$ \\
$\mathbf{1 6 . 0}$ & 100 & $2.92 \mathrm{a}$ & $2.22 \mathrm{~b}$ & $2.18 \mathrm{c}$
\end{tabular}

* Means having the same letter (s) within the same column are not significantly different according to Duncan's multiple range test at $5 \%$ level of probability.

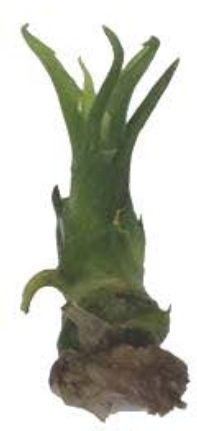

A

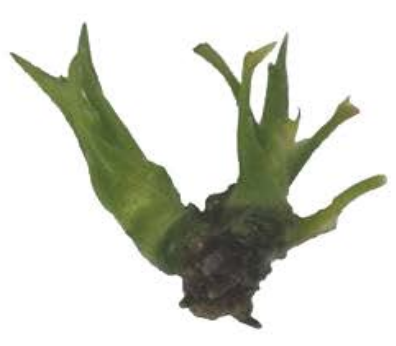

D

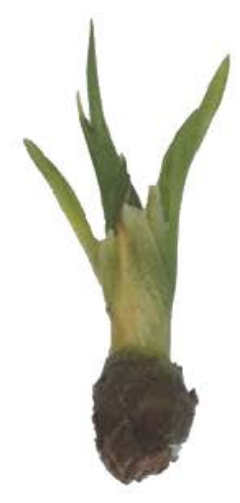

B

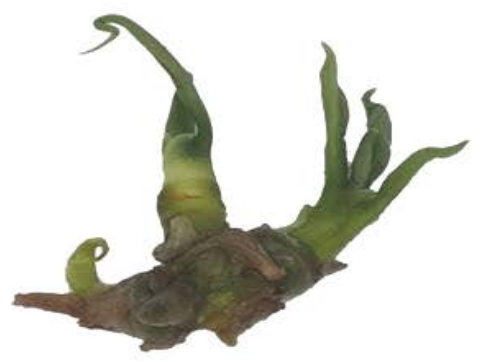

$\mathbf{E}$

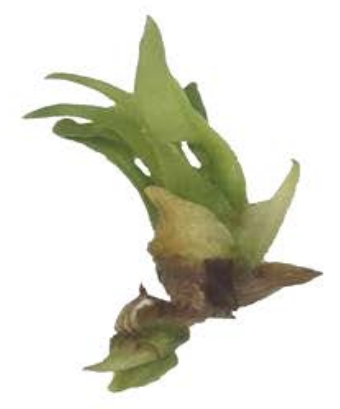

C

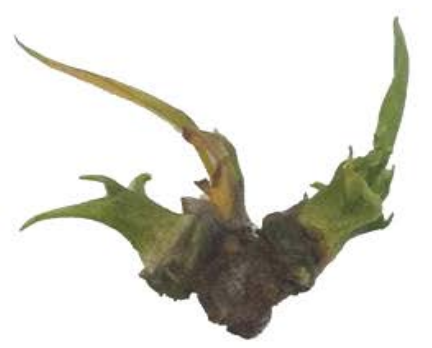

$\mathbf{F}$

Fig. 2. Aglaonema commutatum shoot growth and multiplication as affected by different concentrations of kinetin (Kin) during multiplication stage after 12 weeks. A (without growth regulators), B (1.0 mg/l), C (2.0 mg/l), D (4.0 mg/l), E (8.0 mg/l) and F (16.0 mg/l) 
This enhancing effect of high concentrations (8.0 and $16.0 \mathrm{mg} / \mathrm{l}$ ) of kinetin on shoot multiplication was previously proved by Buah et al. (2010) on Musa sp., Ugraiah et al. (2011) on Caralluma bhupenderiana Sarkaria and Jat et al. (2014) on Asparagus racemosus Wild.

\section{Effect of 2iP Concentration on Shoot Proliferation and Growth}

Data in Table 3 and Fig. 3 illustrate that shoot proliferation did not affect by enriching the medium with $2 \mathrm{iP}$ since all investigated concentrations produced the same proliferation percentage $(100 \%)$. Addition of $2 \mathrm{iP}$ to the medium at low concentration $(1.0 \mathrm{mg} / \mathrm{l})$ did not significantly affect on number of shoots/explant while higher concentrations $(4.0,8.0$ or 16.0 $\mathrm{mg} / \mathrm{l}$ ) significantly enhanced the number of produced shoots on explants without significant differences between these treatments. It was found that supplementation the medium with $2 \mathrm{iP}$ had a negative effect on number of leaves per shoot. Higher concentrations were more pronounced than lower concentrations in this regard. Also, shoot length followed similar trend of number of leaves per shoot.

This beneficial effect of high concentrations of $2 \mathrm{iP}$ on shoot multiplication was earlier confirmed by Shahzad et al. (2012) on Ocimum basilicum and El-Shamy (2013) on Philodendron selloum.

\section{Effect of IAA Concentration Combined with $8.0 \mathrm{mg} / \mathrm{l}$ BA on Shoot Proliferation and Growth}

The above mentioned experiments showed that BA at $8.0 \mathrm{mg} / \mathrm{l} \mathrm{BA}$ was the best treatment for enhancing the number of produced shoots, so this concentration was investigated in combination with different concentrations of auxins (IAA and NAA) in this experiment and the later one.

Data in Table 4 and Fig. 4 indicate that addition of IAA at any concentration was ineffective on shoot proliferation percentage. Also, number of shoots per explants did not significantly response to addition or increasing the concentration except with the highest concentration $(2.0 \mathrm{mg} / \mathrm{l})$ which significantly decreased this character. Number of leaves was significantly inhibited by increasing the concentration of IAA, but without significant difference between 1.0 and $2.0 \mathrm{mg} / \mathrm{l}$. Shoot length did not exhibit any significant response to addition of IAA at any concentration to the culture medium.

This unbeneficial effect for addition IAA to the medium in combination with BA was earlier recorded by Ugraiah et al. (2011) on Caralluma bhupenderiana Sarkaria and Ahmed and Anis (2014) on Vitex trifolia L.

\section{Effect of NAA Concentration Combined with $8.0 \mathrm{mg} / \mathrm{l}$ BA on Shoot Proliferation and Growth}

Supplementation the medium with different concentrations of NAA in combination with 8.0 $\mathrm{mg} / \mathrm{l}$ BA did not affect on shoot proliferation percentage (Table 5 and Fig. 5). The beneficial effect of supplementation the medium with NAA on enhancing the number of produced shoots was recorded with low concentration (0.5 $\mathrm{mg} / \mathrm{l})$ of NAA. This concentration of NAA in combination with $8.0 \mathrm{mg} / \mathrm{l} \mathrm{BA}$ could raise the number of obtained shoots by $67.16 \%$ compared with $8.0 \mathrm{mg} / \mathrm{l} \mathrm{BA}$ alone. On the other side, providing the medium with any concentration of NAA significantly depressed the number of leaves and shoot length without significant differences among different concentrations of NAA.

This synergistic effect between BA and NAA on shoot multiplication and growth which found in this experiment was earlier proved by many investigators such as Anis and Faisal (2005) on Psoralea corylifolia Ahmad et al. (2013) on Vitex negundo Ahmed and Anis (2014) on Vitex trifolia L.

This positive effect of BA + NAA on differential morphogenetic response may be due to apical dominance. Apical dominance is controlled by the ratio of auxin and cytokinin and widely recognized to be caused by the action of basipetally transported auxin from apex and its consequent inhibition of axillary bud growth (Samir, 2004). Thus, it can be inferred from the above results that the interactive effect of BA and NAA could ensure better in vitro regeneration and their synergism in proper concentration was extremely favorable for multiplication. 
Table 3. Effect of isopentenyladenine (2iP) concentration on shoot proliferation and growth of Aglaonema commutatum during multiplication stage after 12 weeks

\begin{tabular}{ccccc}
\hline 2iP conc. (mg/l) & $\begin{array}{c}\text { Shoot proliferation } \\
(\mathbf{\%})\end{array}$ & $\begin{array}{c}\text { No. of shoots/ } \\
\text { explant }\end{array}$ & $\begin{array}{c}\text { No. of } \\
\text { leaves/shoot }\end{array}$ & $\begin{array}{c}\text { Shoot length } \\
\text { (cm) }\end{array}$ \\
\hline $\mathbf{0 . 0}$ & 100 & $1.13 \mathrm{~d}$ & $4.66 \mathrm{a}$ & $4.83 \mathrm{a}$ \\
$\mathbf{1 . 0}$ & 100 & $1.33 \mathrm{~cd}$ & $3.23 \mathrm{~b}$ & $3.23 \mathrm{~b}$ \\
$\mathbf{2 . 0}$ & 100 & $1.80 \mathrm{bc}$ & $2.86 \mathrm{bc}$ & $2.57 \mathrm{c}$ \\
$\mathbf{4 . 0}$ & 100 & $2.26 \mathrm{ab}$ & $2.49 \mathrm{~cd}$ & $2.26 \mathrm{c}$ \\
$\mathbf{8 . 0}$ & 100 & $2.33 \mathrm{a}$ & $2.43 \mathrm{~cd}$ & $2.23 \mathrm{c}$ \\
$\mathbf{1 6 . 0}$ & 100 & $2.53 \mathrm{a}$ & $1.98 \mathrm{~d}$ & $2.27 \mathrm{c}$ \\
\hline
\end{tabular}

* Means having the same letter (s) within the same column are not significantly different according to Duncan's multiple range test at $5 \%$ level of probability.

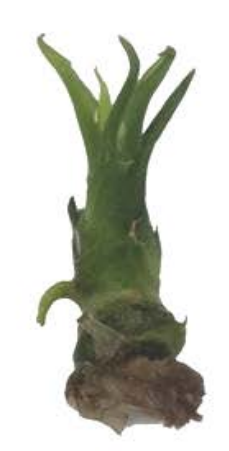

A

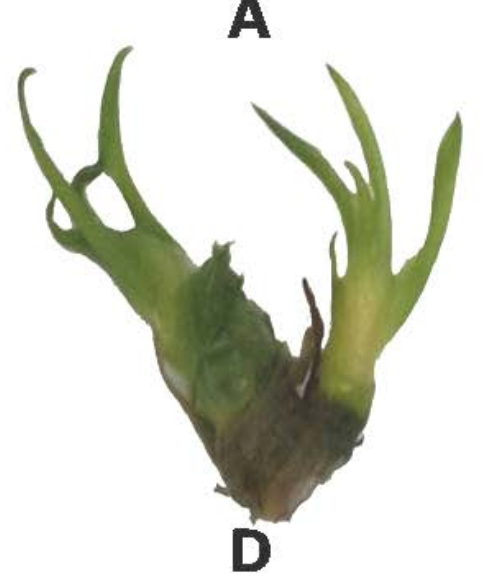

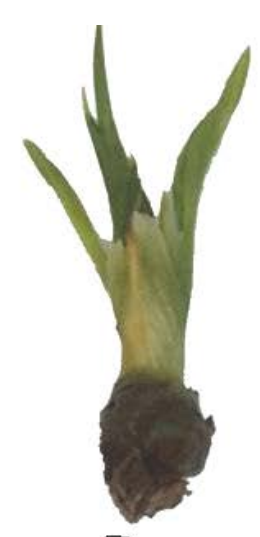

B

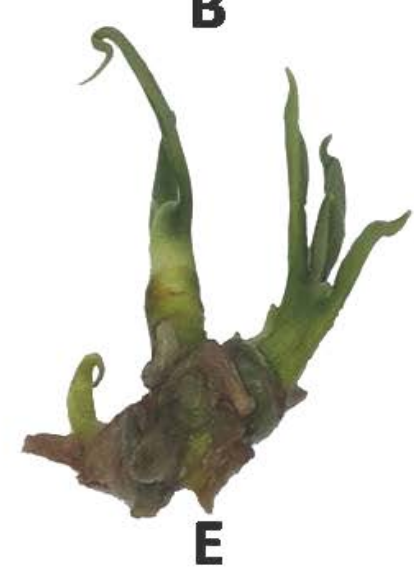

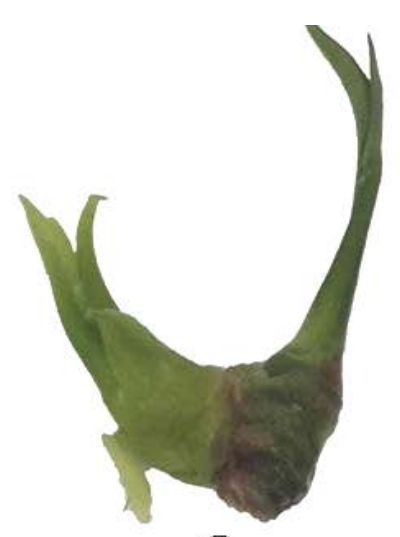

C

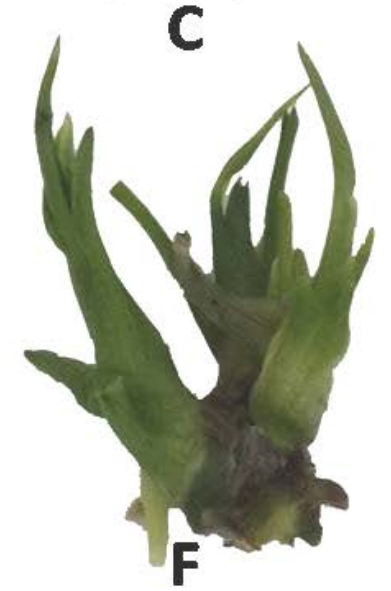

Fig. 3. Aglaonema commutatum shoot growth and multiplication as affected by different concentrations of isopentenyladenine (2iP) during multiplication stage after 12 weeks. A (without growth regulators), B (1.0 mg/l), C $(2.0 \mathrm{mg} / \mathrm{l}), \mathrm{D}(4.0 \mathrm{mg} / \mathrm{l}), \mathrm{E}(8.0 \mathrm{mg} / \mathrm{l})$ and F (16.0 mg/l) 
Table 4. Effect of different concentrations of indoleacetic acid (IAA) combined with $8.0 \mathrm{mg} / \mathrm{l}$ BA on shoot proliferation and growth of Aglaonema commutatum during multiplication stage after 12 weeks

\begin{tabular}{ccccc}
\hline IAA conc. (mg/l) & $\begin{array}{c}\text { Shoot proliferation } \\
\mathbf{( \% )}\end{array}$ & $\begin{array}{c}\text { No. of shoots/ } \\
\text { explant }\end{array}$ & $\begin{array}{c}\text { No. of } \\
\text { leaves/shoot }\end{array}$ & $\begin{array}{c}\text { Shoot length } \\
\text { (cm) }\end{array}$ \\
\hline $\mathbf{0 . 0}$ & 100 & $4.50 \mathrm{a}$ & $2.59 \mathrm{a}$ & $2.26 \mathrm{a}$ \\
$\mathbf{0 . 5}$ & 100 & $4.70 \mathrm{a}$ & $1.92 \mathrm{~b}$ & $2.10 \mathrm{a}$ \\
$\mathbf{1 . 0}$ & 100 & $4.30 \mathrm{a}$ & $1.61 \mathrm{c}$ & $2.20 \mathrm{a}$ \\
$\mathbf{2 . 0}$ & 100 & $1.88 \mathrm{~b}$ & $1.64 \mathrm{c}$ & $1.98 \mathrm{a}$ \\
\hline
\end{tabular}

* Means having the same letter (s) within the same column are not significantly different according to Duncan's multiple range test at $5 \%$ level of probability.

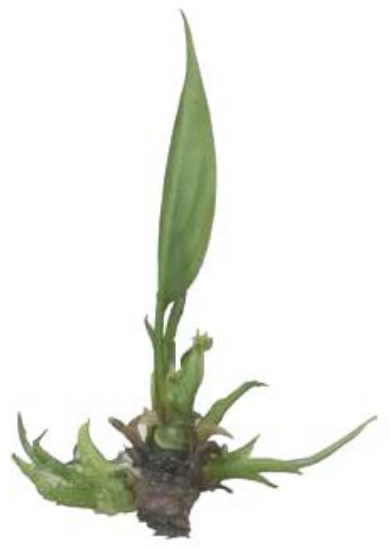

A

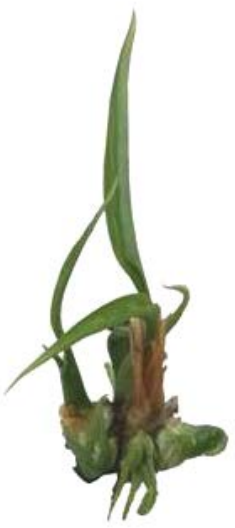

B

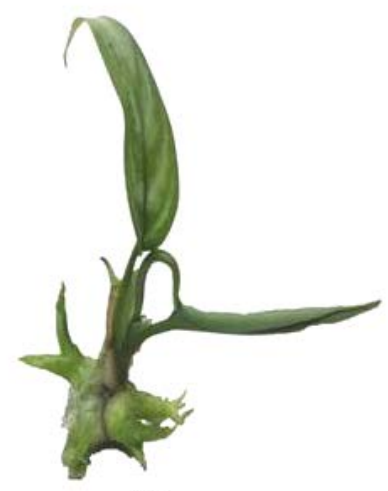

C

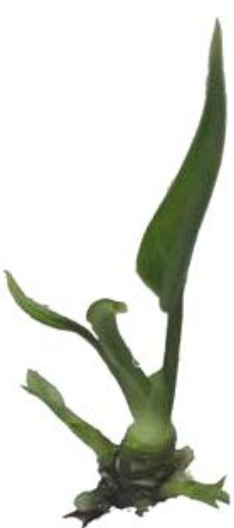

D

Fig. 4. Aglaonema commutatum shoot growth and multiplication as affected by different concentrations of indoleacetic acid (IAA) combined with $8.0 \mathrm{mg} / \mathrm{l}$ BA during multiplication stage after 12 weeks. A (8.0 mg/l BA without IAA), B (0.5 mg/l), C (1.0 $\mathrm{mg} / \mathrm{l})$ and $D(2.0 \mathrm{mg} / \mathrm{l})$

Table 5. Effect of different concentrations of naphthaleneacetic acid (NAA) combined with 8.0 mg/l BA on shoot proliferation and growth of Aglaonema commutatum during multiplication stage after 12 weeks

\begin{tabular}{ccccc}
\hline NAA conc. (mg/l) & $\begin{array}{c}\text { Shoot proliferation } \\
\mathbf{( \% )}\end{array}$ & $\begin{array}{c}\text { No. of shoots/ } \\
\text { explant }\end{array}$ & $\begin{array}{c}\text { No. of } \\
\text { leaves/shoot }\end{array}$ & $\begin{array}{c}\text { Shoot length } \\
\text { (cm) }\end{array}$ \\
\hline $\mathbf{0 . 0}$ & 100 & $4.50 \mathrm{~b}$ & $2.59 \mathrm{a}$ & $2.26 \mathrm{~b}$ \\
$\mathbf{0 . 5}$ & 100 & $6.70 \mathrm{a}$ & $1.93 \mathrm{~b}$ & $2.75 \mathrm{a}$ \\
$\mathbf{1 . 0}$ & 100 & $3.60 \mathrm{c}$ & $1.81 \mathrm{~b}$ & $2.69 \mathrm{a}$ \\
$\mathbf{2 . 0}$ & 100 & $2.70 \mathrm{~d}$ & $2.00 \mathrm{~b}$ & $2.81 \mathrm{a}$ \\
\hline
\end{tabular}

* Means having the same letter (s) within the same column are not significantly different according to Duncan's multiple range test at $5 \%$ level of probability. 

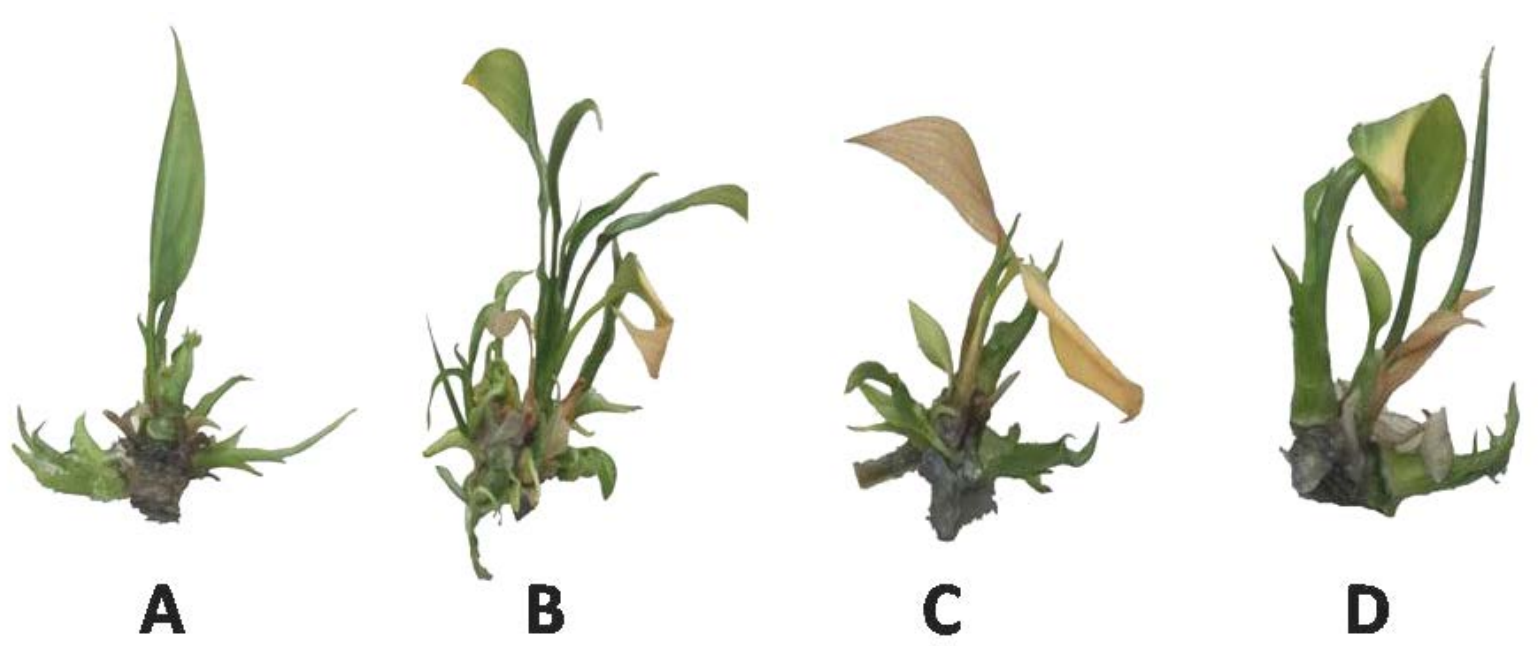

Fig. 5. Aglaonema commutatum shoot growth and multiplication as affected by different concentrations of naphthaleneacetic acid (NAA) combined with $8.0 \mathrm{mg} / \mathrm{l}$ BA during multiplication stage after 12 weeks. A (8.0 mg/l BA without NAA), B (0.5 mg/l), C(1.0 $\mathrm{mg} / \mathrm{l})$ and $D(2.0 \mathrm{mg} / \mathrm{l})$

\section{Effect of IAA, NAA and IBA Concentration on Shoot Rooting and Growth}

As seen in Table 6 and Fig. 6, root formation percentage was enhanced by supplementation the medium with any tested auxin. High concentrations $(0.5,1.0$ or $2.0 \mathrm{mg} / \mathrm{l})$ were more effective than low concentration $(0.25 \mathrm{mg} / \mathrm{l})$ in this regard without differences among different investigated auxins.

Low concentration of IAA was not effective in increasing the number of initiated roots while higher concentrations $(0.5,1.0$ or $2.0 \mathrm{mg} / \mathrm{l})$ significantly raised this character without significant differences among them. Also, increasing of NAA concentration up to $1.0 \mathrm{mg} / \mathrm{l}$ was concomitant with gradual significant enhancing for number of produced roots but the highest concentration $(2.0 \mathrm{mg} / \mathrm{l})$ significantly reduced this parameter. Providing the medium with IBA significantly improved initiation of roots on shoot base. The highest concentration of IBA $(2.0 \mathrm{mg} / \mathrm{l})$ gave the maximum number of roots compared with control or other IBA treatments. In this regard NAA was more effective than other tested auxins since $1.0 \mathrm{mg} / \mathrm{l}$ NAA gave the highest number of roots (19.80) compared with all applied treatments.

Root length was significantly enhanced by addition of IAA to the culture medium. It was gradually increased by raising the concentration up to $1.0 \mathrm{mg} / \mathrm{l}$, while the highest concentration was less effective in this regard. Low concentrations $(0.25$ and $0.5 \mathrm{mg} / \mathrm{l})$ of NAA significantly stimulated the elongation of roots compared with control or higher concentrations (1.0 or 2.0 $\mathrm{mg} / \mathrm{l})$. Supplementation the medium with IBA significantly improved root prolongation. Higher concentrations $(1.0$ or $2.0 \mathrm{mg} / \mathrm{l})$ were more impacted than lower concentrations $(0.25$ and $0.5 \mathrm{mg} / \mathrm{l}$ ) in this concern. The most promising treatment in this regard was $1.0 \mathrm{mg} / \mathrm{l}$ IAA which produced the longest root $(13.50 \mathrm{~cm})$.

This result clearly confirm that NAA was more effective than IAA in enhancing more number of initiated roots on shoot base, while IAA was more effective than NAA in stimulating root elongation. Similar results were recorded by Salvi et al. (2000), Gantait et al. (2009) and Abbas et al. (2011). This variation in effectiveness of different auxin sources may be attributed to their differential affinity to auxin receptors involved in the rooting process, which may be cultivar specific (Tereso et al., 2008). This may be also due to the difference between NAA and IAA stability since IAA tends to be oxidized in culture media and is rapidly metabolized within plant tissues, while NAA is not oxidized, but they can also be converted to conjugates with glucose. IAA is also unstable in 
Table 6. Effect of indoleacetic acid (IAA), naphthaleneacetic acid (NAA) and indole-3butyricacid (IBA) concentrations on Aglaonema commutatum shoot rooting and growth after 12 weeks during rooting stage

\begin{tabular}{|c|c|c|c|c|c|}
\hline $\begin{array}{l}\text { Auxin conc. } \\
\text { (mg/l) }\end{array}$ & $\begin{array}{c}\text { Root } \\
\text { formation } \\
(\%)\end{array}$ & $\begin{array}{l}\text { No. of } \\
\text { roots } \\
\text { /shoot }\end{array}$ & $\begin{array}{l}\text { Root } \\
\text { length } \\
(\mathrm{cm})\end{array}$ & $\begin{array}{c}\text { No. of leaves } \\
\text { /shoot }\end{array}$ & $\begin{array}{c}\text { Shoot length } \\
\text { (cm) }\end{array}$ \\
\hline 0.00 & 40 & $0.75 \mathrm{f}$ & $1.90 \mathrm{f}$ & $4.50 \mathrm{bc}$ & $4.10 \mathrm{~g}$ \\
\hline 0.25 IAA & 90 & $1.40 \mathrm{ef}$ & $7.50 \mathrm{~cd}$ & $4.30 \mathrm{~cd}$ & $4.45 \mathrm{~g}$ \\
\hline 0.50 IAA & 100 & 3.00 de & $9.90 \mathrm{~b}$ & $4.70 \mathrm{abc}$ & $5.60 \mathrm{ef}$ \\
\hline 1.00 IAA & 100 & $4.20 \mathrm{~d}$ & 13.50 a & $5.20 \mathrm{a}$ & $8.00 \mathrm{a}$ \\
\hline 2.00 IAA & 100 & 2.80 de & $6.90 \mathrm{~cd}$ & $5.10 \mathrm{ab}$ & 6.40 de \\
\hline 0.25 NAA & 80 & $7.60 \mathrm{c}$ & $7.00 \mathrm{~cd}$ & $4.30 \mathrm{~cd}$ & $6.70 \mathrm{~cd}$ \\
\hline 0.50 NAA & 100 & $10.40 \mathrm{~b}$ & $8.00 \mathrm{c}$ & 3.70 de & $7.80 \mathrm{ab}$ \\
\hline 1.00 NAA & 100 & 19.80 a & $4.50 \mathrm{e}$ & 3.70 de & $7.50 \mathrm{abc}$ \\
\hline 2.00 NAA & 100 & $7.20 \mathrm{c}$ & $2.15 \mathrm{f}$ & 3.70 de & $4.90 \mathrm{fg}$ \\
\hline 0.25 IBA & 80 & 2.80 de & $5.80 \mathrm{de}$ & $3.60 \mathrm{e}$ & $4.00 \mathrm{~g}$ \\
\hline 0.50 IBA & 100 & 2.80 de & $8.10 \mathrm{c}$ & 3.50 e & $5.40 \mathrm{f}$ \\
\hline 1.00 IBA & 100 & $3.80 \mathrm{~d}$ & 8.60 bc & 3.70 de & $6.90 \mathrm{bcd}$ \\
\hline 2.00 IBA & 100 & $8.70 \mathrm{c}$ & $9.90 \mathrm{~b}$ & 3.80 de & $7.90 \mathrm{a}$ \\
\hline
\end{tabular}

*Means having the same letter (s) within the same column are not significantly different according to Duncan's multiple range test at $5 \%$ level of probability.
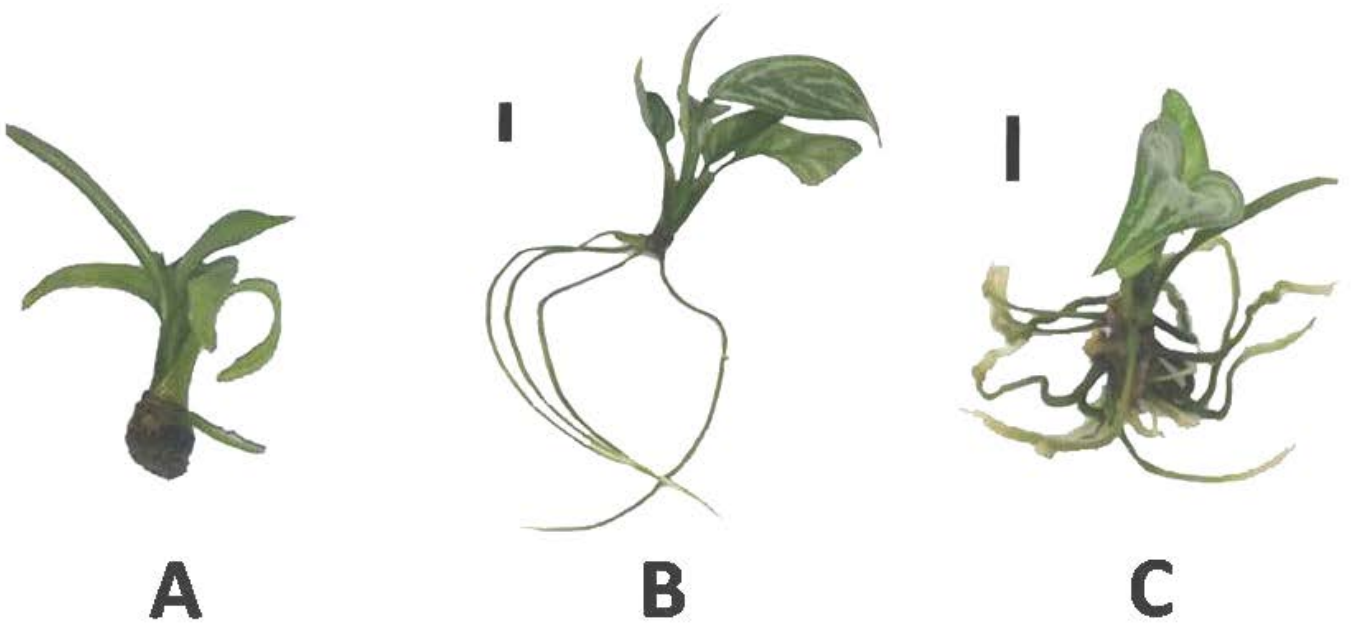

Fig. 6. Aglaonema commutatum shoot rooting and growth as affected by control treatment (without growth regulators, $A$ ) and the best rooting treatments; i.e., $1.0 \mathrm{mg} / \mathrm{l}$ IAA (B) and $1.0 \mathrm{mg} / \mathrm{l}$ NAA (C) after 12 weeks during rooting stage. $B a r s=1.0 \mathrm{~cm}$ 
culture media at room temperature. In the dark, it can be more than a ten-fold decrease in concentration over a four-week period in the absence of inoculation (George et al., 2008).

Generally, number of leaves did not significantly affect by addition of IAA to the medium except with the concentration of 1.0 $\mathrm{mg} / \mathrm{l}$ which significantly surpassed control treatment. There was no significant difference between low concentration $(0.25 \mathrm{mg} / \mathrm{l})$ of NAA and control treatment, while higher concentrations significantly decreased the number of leaves without significant differences among them. All concentrations of IBA significantly declined the number of leaves initiated on shoot without significant differences among them.

Increasing of IAA concentration up to 1.0 $\mathrm{mg} / \mathrm{l}$ was associated with gradual enhancing in shoot length, while higher concentration (2.0 $\mathrm{mg} / \mathrm{l})$ was less effective in this regard. Similar trend was recorded with NAA. Concerning the effect of IBA, it was found that as the IBA concentration increased, the shoot length significantly enhanced throughout the range examined. It is worth to note that, the highest shoot lengths ( 8.00 and $7.90 \mathrm{~cm}$ ) were belonged to $1.0 \mathrm{mg} / \mathrm{l}$ IAA and $2.0 \quad 1.0 \mathrm{mg} / \mathrm{l}$ IBA (respectively) without significant difference between both of them. This result was in harmony with those obtained by El-Shamy (2013) on Philodendron selloum.

The above mentioned results suggest that 1.0 $\mathrm{mg} / \mathrm{l}$ of IAA or NAA were the best treatments for root induction and quality during rooting stage (Fig. 6). Our recommendation is to use 1.0 $\mathrm{mg} / \mathrm{l}$ NAA since the other treatment produced too long root which may be subjected to broken during acclimatization.

\section{Effect of Different Planting Media on Survivability and growth of Plantlets}

Since the successful ex vitro acclimatization of micropropagated plants determines the quality of the end product and, in commercial production, the economic viability of the enterprise this experiment was conducted to evaluate some planting media efficiency during acclimatization stage.

Data in Table 7 and Fig. 7 illustrate that most investigated media gained the maximum survivability percentage (100\%), while using peat moss or peat moss + sand $(1: 1, V / V)$ came in the second order (80\%) and employing peat moss + vermiculite: sand $(1: 1: 1, \quad$ V/V/V) occupied the last order (70\%). In most cases, No. of shoots/ plantlet did not significantly affect by acclimatization media type. The highest significant number of leaves/ shoot and plantlet length $(7.40$ and $9.0 \mathrm{~cm}$, respectively) were achieved by using of perlite and peat moss at equal volume proportions. This medium seems to be the best medium for acclimatization Aglaonema commutatum plantlets. This result was in harmony with those obtained by Offord and Campbell (1992), Hashem et al. (2006) and Viñas et al. (2012).

Table 7. Effect of some planting media on survival percentage and growth of Aglaonema commutatum plantlets after eight weeks during acclimatization stage

\begin{tabular}{|c|c|c|c|c|c|c|c|}
\hline \multicolumn{4}{|c|}{ Planting medium } & \multirow{2}{*}{$\begin{array}{c}\text { Survival } \\
(\%)\end{array}$} & \multirow{2}{*}{$\begin{array}{l}\text { No. of } \\
\text { shoots/ } \\
\text { plantlet }\end{array}$} & \multirow{2}{*}{$\begin{array}{c}\text { No. of } \\
\text { leaves/ } \\
\text { shoot }\end{array}$} & \multirow{2}{*}{$\begin{array}{c}\text { Plantlet } \\
\text { length }(\mathrm{cm})\end{array}$} \\
\hline Perlite & Peat moss & Vermiculite & Sand & & & & \\
\hline 0 & 1 & 0 & 0 & 80 & $1.00 \mathrm{~b}$ & $3.70 \mathrm{~cd}$ & $3.90 \mathrm{e}$ \\
\hline 1 & 1 & o & o & 100 & $1.10 \mathrm{ab}$ & $7.40 \mathrm{a}$ & $9.00 \mathrm{a}$ \\
\hline 1 & 1 & 1 & $\mathbf{0}$ & 100 & $1.10 \mathrm{ab}$ & $4.50 \mathrm{c}$ & $5.50 \mathrm{~cd}$ \\
\hline 1 & 1 & 1 & 1 & 100 & $1.10 \mathrm{ab}$ & $5.70 \mathrm{~b}$ & $7.60 \mathrm{ab}$ \\
\hline $\mathbf{0}$ & 1 & 1 & $\mathbf{0}$ & 100 & $1.30 \mathrm{a}$ & $6.10 \mathrm{~b}$ & $6.60 \mathrm{bc}$ \\
\hline $\mathbf{0}$ & 1 & $\mathbf{0}$ & 1 & 80 & $1.00 \mathrm{~b}$ & $3.40 \mathrm{~cd}$ & 3.80 e \\
\hline $\mathbf{0}$ & 1 & 1 & 1 & 70 & $1.00 \mathrm{~b}$ & $3.00 \mathrm{~d}$ & $4.40 \mathrm{de}$ \\
\hline
\end{tabular}

* Means having the same letter (s) within the same column are not significantly different according to Duncan's multiple range test at $5 \%$ level of probability. 


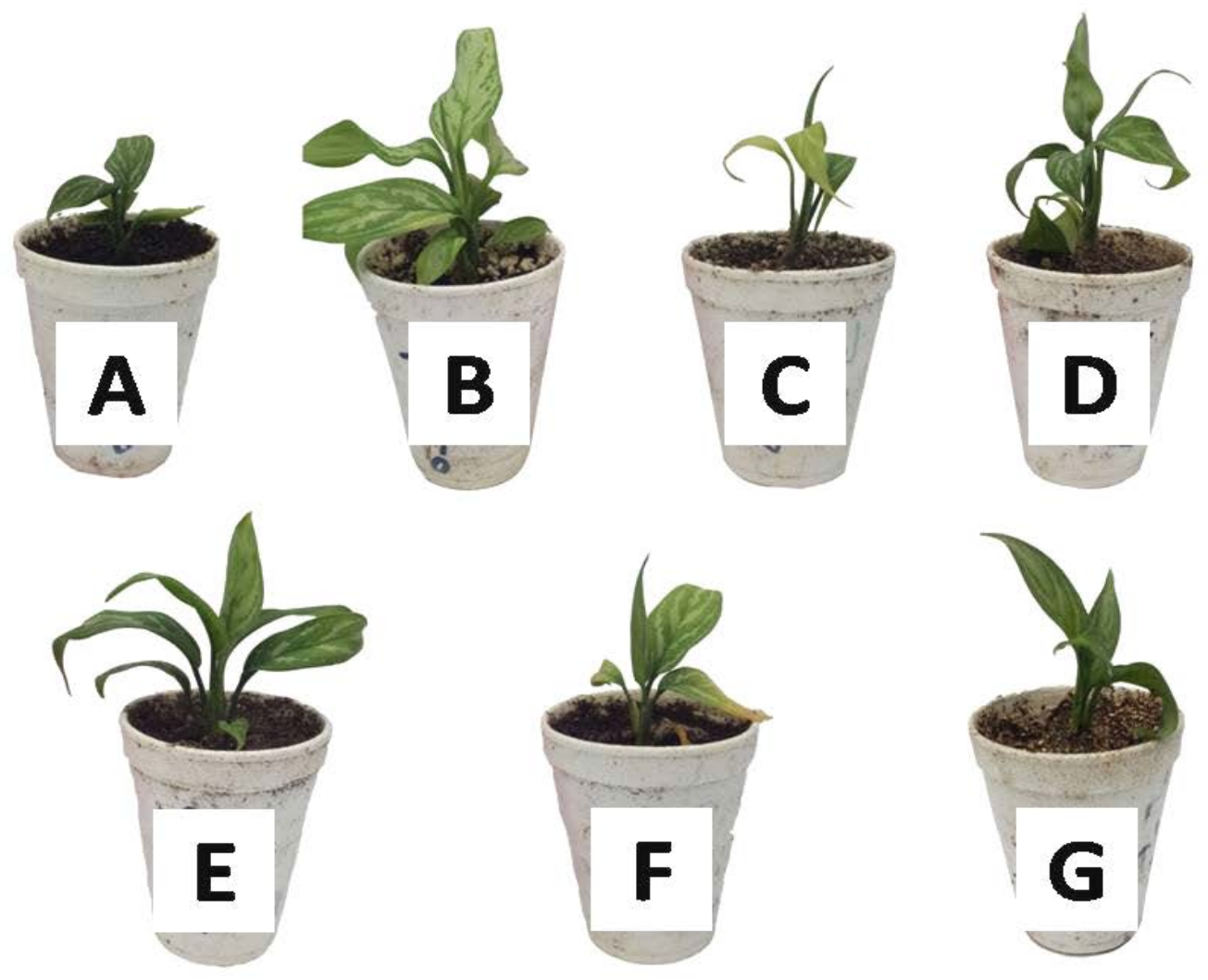

Fig. 7. Effect of some planting media on Aglaonema commutatum plantlet growth after eight weeks during acclimatization stage.(A) peat moss, (B) peat moss + perlite $(1: 1, V / V),(C)$ perlite + peat moss + vermiculite (1:1:1, $V / V / V)$, (D) perlite + peat moss + vermiculite + sand (1:1:1:1, $V / V / V / V)$, (E) peat moss + vermiculite $(1: 1, V / V)$, (F) peat moss + sand (1:1, $V / V)$ or $(G)$ peat moss + vermiculite + sand $(1: 1: 1, V / V / V)$

\section{REFERENCES}

Abbas, M.S., H.S. Taha, U.I. Aly, H.M. ElShabrawi and E.I. Gaber (2011). In vitro propagation of ginger (Zingiber officinale Rosco). J. of Gen. Eng. and Biotech, 9: 165172.

Abdi, G., M. Hedayat and M. Modarresi (2013). In vitro micropropagation of Aloe veraimpacts of plant growth regulators, media and type of explants. J. Biol. Environ. Sci., 7 (19): 19-24.

Ahmad, N., M.I. Khan, S. Ahmed, S.B. Javed, M. Faisal, M. Anis, S. Rehman and S.M. Umair (2013). Change in total phenolic content and antibacterial activity in regenerants of Vitex negundo L. Acta Physiol. Plant, 35: 791-800.
Ahmed, R. and M. Anis (2014). Rapid in vitro propagation system through shoot tip cultures of Vitex trifolia L.-an important multipurpose plant of the Pacific traditional medicine. Physiol. Mol. Biol. Plants, 20 (3): 385-392.

Anis, M. and M. Faisal (2005). In vitro regeneration and mass multiplication of Psoralea corylifolia-an endangered medicinal plant. Indian J. Biotechnol., 4 (2): 261-264.

Buah, J.N., K.J. Danso, K.J. Taah, E.A. Abole, E.A. Bediako, J. Asiedu and R. Baidoo (2010). The effect of different concentrations of cytokinins on the in vitro multiplication of plantain (Musa sp.). Biotechnol., 9 (3) : 343347. 
Chase, A.R. (1997). Foliage Plant Diseases: Diagnosis and Control. Ame. Phytopathol. Soc., St. Paul, Minn., 8-11.

Chen, J., D.B. McConnell, D.J. Norman and R.J. Henny (2005). The foliage plant industry. Hort. Rev., 31: 45-110.

Chen, W.L. and D.M. Yeh (2007). Elimination of in vitro contamination, shoot multiplication, and ex vitro rooting of Aglaonema. Hort. Sci., 42 (3): 629-632.

El-Shamy, H.A. (2013). Preliminary protocol for mass micropropagation of Philodendron selloum. Zagazig J. Agric. Res. 40 (5): 839849.

Fang, J., Y. Hsu and F. Chen (2013). Development of an efficient micropropagation procedure for Aglaonema 'Lady Valentine' through adventitious shoot induction and proliferation. Plant Biotechnol., 30: 423-431.

Gantait, S., N. Mandal and P.K. Das (2009). Impact of auxins and activated charcoal on in vitro rooting of Dendrobium chrysotoxum Lindl. cv. Golden Boy. J. Tropical Agric., 47 (1-2): 84-86.

George, E.F., M.A. Hall and G.D. Klerk (2008). Plant Propagation by Tissue Culture. Springer Publisher, Dordrecht, Netherlands.

Gomez, K.A. and A.A. Gomez (1984). Statistical Procedures for Agricultural Research. Wiley, New York, USA.

Hang, P.T., N.T. Hai, N.T. Linh, N.T. Thuy, D.T. Tam and N.T. Thao (2013). In vitro micropropagation of Philodendron xanadu. J. Sci. and Develop., 11 (6): 826-832.

Hashem, M.E., A.M.A. Gayed, F.M. Saadawy and W.A. Aly (2006). Studies on the micropropagation of lily (Lilium longiflorum Thunb) bulbs. III- Rooting and acclimatization. An. Agric. Sci., Cairo, 51 (2): 485-496.

Henny, R. (2000). Breeding Ornamental Aroids. In: Callaway D.J., Callaway M.B. (Eds.). Breeding Ornamental Plants. Timber Press, Portland, 121-132.

Jat, B.L., R.K. Maheshwari, R. Lomror and C.R. Choudhary (2014). In vitro regeneration with callus development of Asparagus racemosus by epicotyledonary node. J. Pharmaceutical and Biol. Res., 2 (1): 69-78.

Mariani T.S., A. Fitriani, J.A. Teixeira da Silva, A. Wicaksono and T.F. Chia (2011). Micropropagation of Aglaonema using axillary shoot explants. Int. J. Basic Appl. Sci., 11: 46-53.

Michigan State University (1983). MSTAT-C Micro Computer Statistical Programe, Version 2. Michigan State University, East Lansing.

Murashige, T. and F. Skoog (1962). A revised medium for rapid growth and bioassays with tobacco tissue culture. Physiologia Plantarum, 15: 473- 497.

Offord, C.A. and L.C. Campbell (1992). Micropropagation of Telopea speciosissima R. Br. (Proteaceae). 2: Rhizogenesis and acclimatization to ex vitro conditions. Plant Cell, Tissue and Organ Cult., 29: 223-230.

Salvi, N.D., L. George and S. Eapen (2000). Direct regeneration of shoots from immature inflorescence cultures of turmeric. Plant Cell, Tissue and Organ Cult., 62: 235-238.

Samir, C.D. (2004). Clonal propagation of dwarf raspberry (Rubus pubescens Raf.) through in vitro axillary shoot proliferation. Plant Growth Regul., 43:179-186.

Shahzad, A., M. Faisal, N. Ahmad, M. Anis, A. Alatar and A.H. Alwathnani (2012). An efficient system for in vitro multiplication of Ocimum basilicum through node culture. Afr. J. Biotechnol., 11(22): 6055-6059.

Stickens D., W. Tao and J.P. Verbelen (1996). A single cell model system to study hormone signal transduction. Plant Growth Regul., 18: 149-154.

Tereso, S., C.M. Miguel, M. Mascarenhas, A. Roque, H. Trindade, J. Maroco and M.M. Oliveira (2008). Improved in vitro rooting of Prunus dulcis Mill. cultivars. Biol. Plant, 52: 437-444.

Ugraiah, A., V.R. Sreelatha, P.V.K. Reddy, K. Rajasekhar, S.S. Rani1, S. Karuppusamy and T. Pullaiah (2011). In vitro shoot multiplication and conservation of Caralluma 
bhupenderiana Sarkaria - an endangered medicinal plant from South India. Afr. J. Biotechnol., 10 (46): 9328-9336.

Viñas, M., M. Fernández-Brenes, A. Azofeifa and V.M. Jiménez (2012). In vitro propagation of purple pitahaya (Hylocereus costaricensis [F.A.C. Weber] Britton and
Rose) cv. Cebra. In vitro Cell. Dev. Biol.Plant 48:469-477.

Zhang S., R. Jiang and H. Zhou (2004). Study on rapid propagation of Aglaonema commutatum cv. 'Golden Jewelry'. Chin. Agric. Sci. Bull., 20: 39-40.

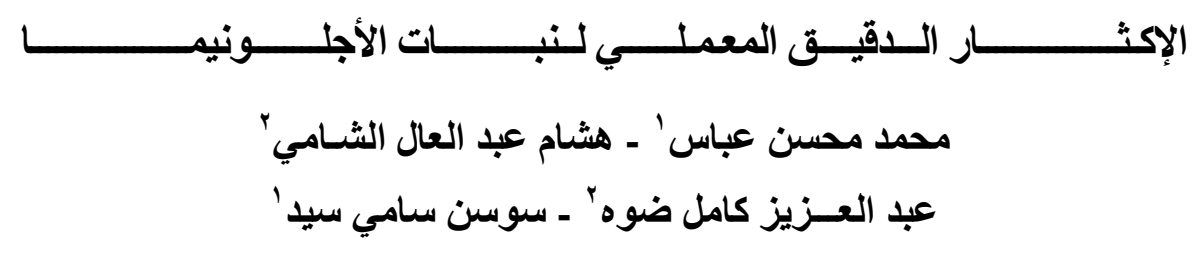

$$
\text { r ـ ـ قـم الزينة ـ معهد بحوث البساتين - مركز البحوث الزر اعية ـ وزارة الزراعة ـ مصر }
$$

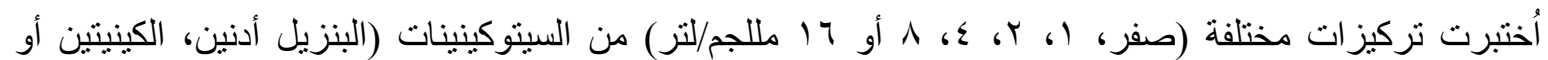

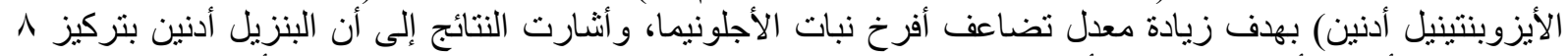

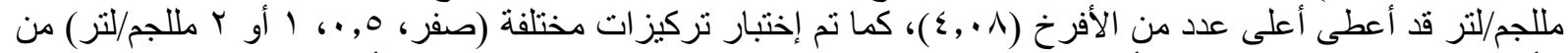

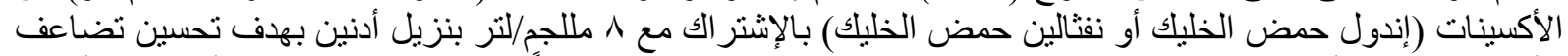

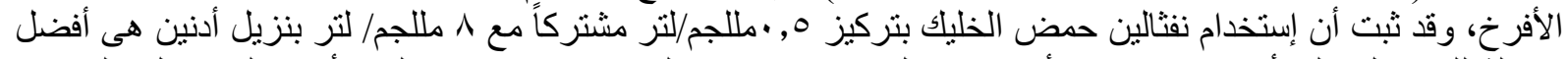

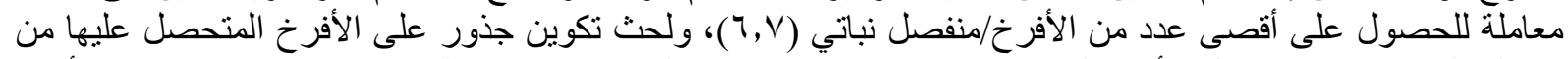

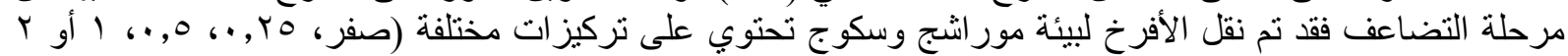

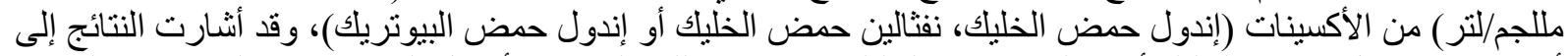

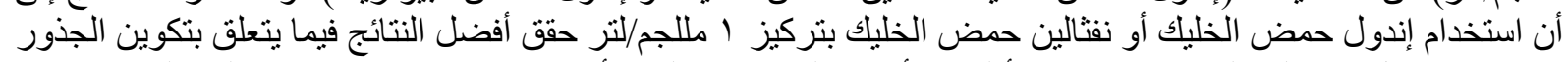

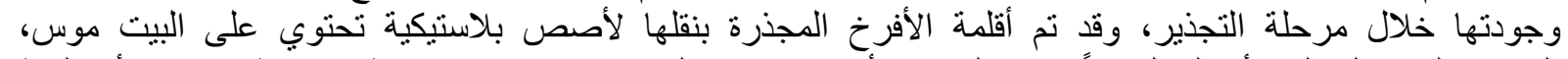

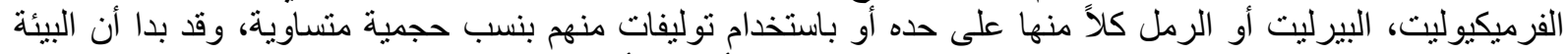
المحتوية على البيرليت والبيت موس بنسب حجمية منساوية هي الأفضل لأقلمة النبيتات. 